\title{
MORPHOMETRY OF KNEE MENISCI
}

\section{Sivasakthi $\mathbf{M}^{1}$, Yogesh Ashok Sontakke ${ }^{2 *}$, Aravindhan $\mathbf{K}^{3}$ \\ ${ }^{1}$ Junior Resident, ${ }^{2}$ Associate Professor,}

*1,2 Department of Anatomy, Jawaharlal institute of Postgraduate Medical Education and Research (JIPMER),

${ }^{3}$ Professor Senior scale, Department of Anatomy, Jawaharlal institute of Postgraduate Medical Education and Research (JIPMER) (An Institution of National Importance under the Ministry of Health \& Family Welfare, Govt. of India), Pondicherry, 605006 India.

*Corresponding author:

Email:dryogeshas@rediffmail.com

\begin{abstract}
: -
Menisci is one of the most important structures of the knee joint. Owing to its importance in load sharing, shock absorption, joint stability, overall protection of articular cartilage various studies has been done on the morphometry of knee menisci by different researchers. Different parameters have been studied such as length of outer circumference of both menisci, difference between anterior horn and posterior horn of menisci, thickness and width of menisci. Such parameters have been reviewed in this article. It gives out a wider knowledge about the morphometric parameters of knee menisci and may guide the surgeon for the new treatment modalities in case of meniscal injuries.
\end{abstract}

Key words: knee joint, menisci, medial meniscus, lateral meniscus, morphometry.

\section{(ㄷ) (\$) (1)}




\section{INTRODUCTION}

Knee joint is the largest of all synovial joints in the body. It is a compound joint includes two condylar joints between femur and tibia, being partly divided by menisci. Meniscus is a fibrocartilaginous structure that preserves articular cartilage integrity in the knee and contribute to a healthy knee joint. Meniscus has a dense extracellular matrix composed of water $(72 \%)$ and collagen (22\%), interrupted with cells. Proteoglycans, noncollagenous proteins and glycoproteins account for the remaining dry weight. The cells of menisci are referred to as fibrochondrocytes because they appear to be a mixture of fibroblasts and chondrocytes. The semicircular medial meniscus is broader posteriorly than anteriorly. The anterior horn is attached to the tibial plateau near intercondylar fossa anterior to the anterior cruciate ligament (Figure 1). The posterior horn is attached to posterior condylar fossa of tibia between the lateral meniscus and posterior cruciate ligament. Lateral meniscus is nearly circular with an approximate uniform width from anterior to posterior (Figure 1). Menisci have several functions such as maintaining congruency, load

transmission, increase in joint contact area, decrease in joint contact stress, shock absorption, lubrication and limitation of extreme movements ${ }^{1}$. As menisci perform several important functions, they are frequently exposed to injuries. Given the important role of menisci in maintaining joint stability, it is not surprising that a torn meniscus or a surgically removed menisci are well known to disturb the normal anatomy in the knee joint and results in early articular damage ${ }^{9}$. For this, morphometric parameters like thickness, width, length of outer circumference of menisci and distance between anterior and posterior horn of both menisci helps in successful restoration of native menisci and helps in maintain the congruity of knee joint ${ }^{2}$.

\section{MATERIALS AND METHODS}

Search Engine: PubMed. For writing review on menisci morphometry. PubMed is used as a Search Engine. Key words used are menisci, morphometry and anatomy. Articles included in this review were related to the parameters on width, thickness, length of outer circumference, distance between Anterior horn and posterior horn of both menisci. Studies involving animal studies and articles other than English language were also excluded.

\section{REVIEW}

\section{Reviewed Morphometry of Menisci}

In this article, the parameters that reviewed are as length of outer circumference, width, thickness, difference between anterior horn and posterior horn of both menisci. The thickness of medial meniscus ranges as is the anterior third $5.40 \pm$ 0.5 to $6.40 \pm 1.3 \mathrm{~mm}$ middle third $5.2 \pm 1.3$ to $6.43 \pm 1.15 \mathrm{~mm}$ posterior third 5.18 to $6.72 \pm 1.12$ and lateral menisci as anterior third $3.71 \pm 1.15$ to $5.90 \pm 0.33 \mathrm{~mm}$ middle third $5.00 \pm 0.56$ to $6.75 \pm 1.13 \mathrm{~mm}$ posterior third $5.29 \pm 0.78$ to $7.0 \pm 0.60 \mathrm{~mm}$. The width of lateral menisci ranges as anterior third $7.37 \pm 1.0$ to $11.86 \pm 1.81 \mathrm{~mm}$ middle third $8.6 \pm 1.2$ to $12.53 \pm 0.72 \mathrm{~mm}$ posterior third $9.80 \pm 1.16$ to $12.03 \pm 0.8 \mathrm{~mm}$ and medial menisci ranges as anterior third $7.37 \pm 1.06$ to $10.02 \pm 1.59 \mathrm{~mm}$ middle third $7.8 \pm 1$ to $12.16 \pm 2.58 \mathrm{~mm}$ posterior third $13.9 \pm 0.8$ to $17.37 \pm 2.22 \mathrm{~mm}$. The distance between anterior horn and posterior horn of medial menisci ranges as $25.88 \pm 3.33 \mathrm{~mm}$ to $3.25 \pm 0.37 \mathrm{~cm}$ lateral menisci ranges as $12.6 \pm 0.98 \mathrm{~mm}$ to $12.55 \pm 1.98 \mathrm{~mm}$. The length of outer circumference of medial menisci ranges as $86.4 \pm 0.27$ $\mathrm{mm}$ to $10.50 \pm 0.65 \mathrm{~cm}$ and lateral menisci ranges as $87.3 \pm 0.65 \mathrm{~mm}$ to $10.15 \pm 0.72 \mathrm{~cm}$

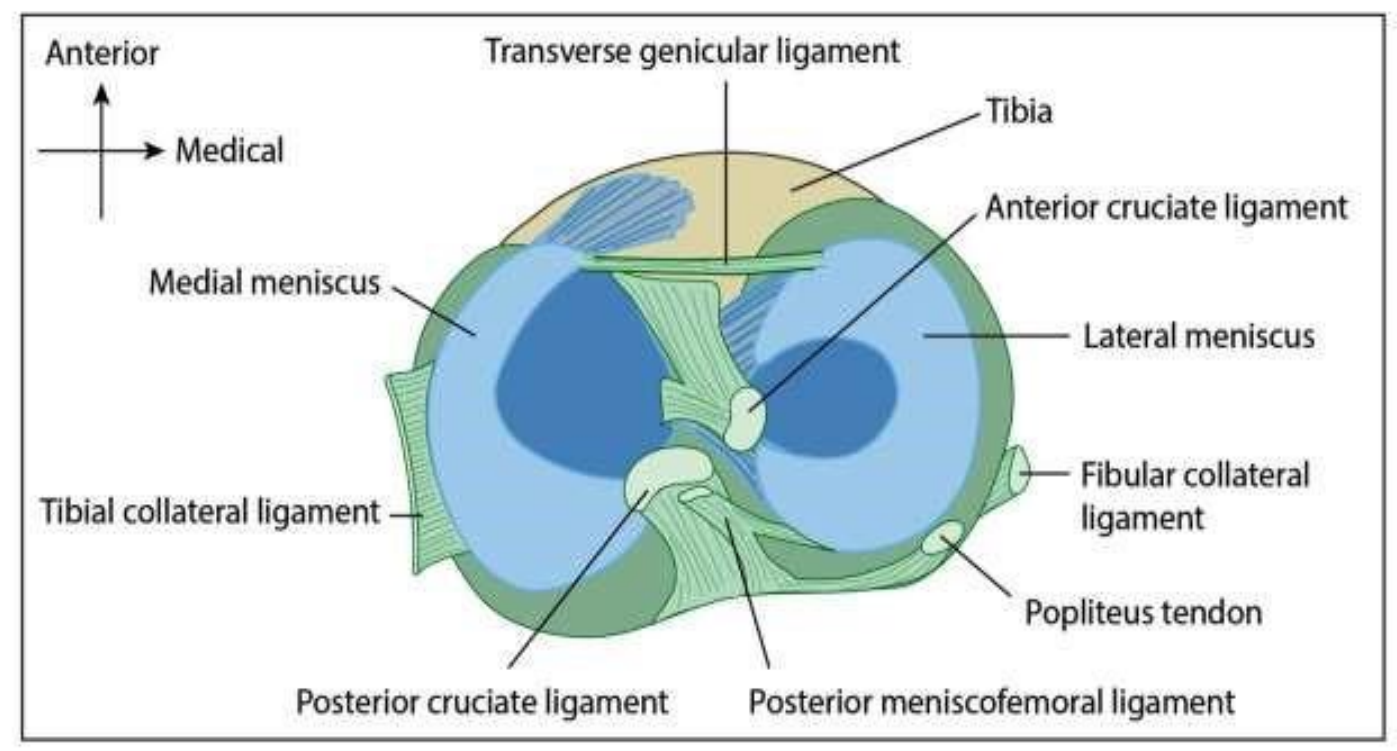

Figure 1: Superior view of tibia showing the attachment of menisci.

\section{DISCUSSION}

Menisci of knee joint plays a vital role in maintaining stability of knee joint, movements, load transmission and shock absorption ${ }^{1}$. As meniscus is more prone to injury, the study on it morphometry plays an important role in the treatment of meniscal injuries. Researchers used various modalities for finding the different parameters. Parameters discussed are 
Thickness of both menisci with regard to anterior third, middle and posterior third.

Width of both menisci with regard to anterior third, middle third and posterior third.

Length of outer circumference of both menisci.

Distance between Anterior and posterior horn of both menisci.

Shape of menisci.

Researchers used following instruments and methods for morphometric analysis: Digital

Vernier caliper, conventional methods using non- elastic cotton thread, silk thread, magnetic resonance imaging ,3D

MRI scopy, analogical pachymeter, sagittal and coronal T1-weighted and T2 weighted MRI images

\section{Thickness of menisci}

For calculating thickness of menisci researchers have used different methods and techniques in cadavers and living subjects. The common technique used was digital Vernier caliper to calculate the thickness of menisci that is measured with the help of a non-elastic cotton thread at three different levels as anterior, middle and posterior ${ }^{(1,2,5,6)}$. Dhanajaya et al. done the study with 40 cadavers and measured the parameters using sagittal and coronal $\mathrm{T} 1$ weighted and T2 weighted MRI Images ${ }^{7}$. Bloecker et al. done the study using healthy male subjects using MR imaging/3D morphometric analysis and found the maximal thickness of both menisci ${ }^{9}$. This is the first study to directly compare the morphometry of knee menisci in healthy adult knees without osteoarthritis ${ }^{9}$. From the above studies it is found that in medial meniscus, the middle third is the thinnest and hence, this region is more prone for injury.

\section{Width of menisci}

The other important parameter in the menisci is width that plays a major role in determining the possibility and the kind of injury. Many researchers defined the width using cadavers and living subjects with techniques that has been used to measure the thickness of menisci. Most common technique used in width measurement is using digital Vernier caliper. Other techniques used are sagittal and coronal T1 \& T2 weighted MRI images and MR imaging technique ${ }^{(1,2,5,7,7,9)}$. The values of different studies are mentioned in Table 3 and 4 . From the values observed it is found that there is no significant variation in the menisci in the anterior and middle region except for the posterior region of the medial meniscus proved to be the widest followed by the other parts; whereas, in the lateral meniscus there is no significant variation were found in the width between the 3 parts of the lateral meniscus.

\section{Length of outer circumference of menisci}

The length of the outer circumference of menisci is other important parameter to be known in meniscus restoration following an injury or following some degenerative changes. The most common technique used in the measurement of length is using nonelastic cotton thread which is measured using digital Vernier caliper. Different researcher studied and recorded the length of the outer circumference of both medial and lateral menisci and the values are slatted in the Table $5^{(1,2,5,8)}$. It can be clearly understood from the Table 5 that there is no significant difference between the length of the outer circumference of medial and lateral meniscus

\section{Difference between the anterior and posterior horns of menisci}

The other parameter in the determination of shape of menisci that plays a major role in maintaining congruency of knee joint is the distance between the anterior and posterior horns of both menisci. Rao et al. studied this using 50 embalmed human cadavers using nonelastic cotton thread and the measurements were taken with Vernier caliper. He found that there is significant variation in the distance between the anterior and posterior hons of both menisci and the values recorded had been quoted in the Table $6^{(1,2,5)}$. The larger interruption between the horn of medial menisci indicates that medial menisci is more like half-moon and the lateral menisci resembles an almost complete ring thereby compensating for the difference in size of tibial plateau bordered by the menisci, this can explain why the outer circumference measures of the adjacent menisci shows no significant difference ${ }^{1}$. This finding is very important clinical aspect whereby the close proximity of the two horns of lateral menisci makes it less prone for injury ${ }^{1}$. Following Rao et al., many researchers described the parameter using Vernier caliper and their values are in accordance with the previous studies

\section{Shape of menisci}

The meniscus is a wedge-shaped piece of cartilage that sits in between the bones of the knee and acts as a cushion to protect the bones during active movement. The anatomical variations of the intraarticular structures of the knee joint has emerged to be very important in the advent of knee arthroscopy and various imaging modalities as these variations determines the frequency and severity of knee injuries. Muralimanju et al. discussed the morphology of meniscus using 27 human cadavers of the south Indian population ${ }^{3}$. Morphological variants of medial menisci were sub-grouped as sickleshaped, sided U-shaped, sided V-shaped, crescent-shaped and C-shaped. The lateral meniscus was sub-grouped as crescent-shaped, Cshaped and discoid-shaped. Among these, discoid menisci is more frequent to get torn. The vast majority of discoid menisci are lateral, whereas the medial discoid menisci are rare ${ }^{3}$.

Discoid menisci are again classified as incomplete, complete, hypermobile wrisberg.

Incomplete discoid meniscus is the common to occur among others. 


\section{REFERENCE}

[1].Rao N, Gupta AD, Raju AV. Morphometric analysis of the menisci of the knee joint in population of East Godavari region of Andhra Pradesh. JEMDS. 2014;34(3):89728979.

[2].Rohila J, Rathkee SK, Dhattarwal SK, Kundu ZS. Morphometric analysi of menisci of adult human knee joint in North Indian population. IJRMS. 2017;2(5):569-573.

[3].Murlimanju BV, Nair N, Pai S, Pai M, Chetan P, Gupta C. Morphological study of the knee menisci of the knee joint in adult cadavers of South Indian population. Marmara Med J. 2010;23(2):270-275.

[4].Fox AJS, Bedi D, Rodeo SA. The Basic Science of Human Knee Menisci: Structure, Composition and Function. Sports Health: A Multidisciplinary Approach. 2012;4(4):340-51.

[5].Kaur A, Sodhi S. Morphometric study of Medial Menisci of the knee joint in thirty Adult Male Cadavers. J Acad Industrial Res. 2013;4(2):226-229.

[6].Almeida KSS, Moraes SRA,Tashiro T, Neves ES, Toscano AE, Abreu RMR. Morphometric study of menisci of the knee joint. Int J Morphol. 2004;22(3):181-184.

[7].Dhananjaya KVN et al.In vivo morphometry of menisci of the knee in South Indians: A Preliminary study. Biomed J. 2014;37:14-17.

[8].Hathila BS, Vyas KK, Vaniya VH, Kodiyatar BB. Morphological study of menisci of knee joint in human cadavers. Internat J Anat Radio Sur. 2018;7(4):AO10-AO14.

[9].Bloecker K, Wirth W, Hudelmaier M, Burgkart R, Frobell R, Eckstein F. Morphometric differences between the medial and lateral meniscus in healthy men- A three-dimensional analysis using magnetic Resonace Imaging. Cells Tissues Organs. 2012; 195:353-364.

Table 1: Thickness of medial meniscus

\begin{tabular}{|c|c|c|c|c|c|c|c|}
\hline \multirow[b]{2}{*}{ Author } & \multirow[b]{2}{*}{$\begin{array}{l}\text { Yea } \\
\text { r }\end{array}$} & \multirow{2}{*}{$\begin{array}{l}\text { Typ } \\
\text { e of } \\
\text { stud } \\
\text { y }\end{array}$} & \multirow{2}{*}{$\begin{array}{l}\text { No. of } \\
\text { Knee } \\
\text { Joint }\end{array}$} & \multirow[b]{2}{*}{ Method } & \multicolumn{3}{|c|}{ Medial meniscus } \\
\hline & & & & & $\begin{array}{l}\text { Anterior } \\
(\mathbf{m m})\end{array}$ & Middle (mm) & $\begin{array}{l}\text { Posterior } \\
(\mathbf{m m})\end{array}$ \\
\hline Rao et al. ${ }^{1}$ & 2014 & $\mathrm{C}$ & 100 & $\begin{array}{l}\text { Non-elastic } \\
\text { cotton thread } \\
/ \quad \text { Vernier } \\
\text { caliper }\end{array}$ & $5.40 \pm 0.5$ & $5.60 \pm 0.60$ & $5.4 \pm 0.50$ \\
\hline $\begin{array}{l}\text { Rohila et } \\
\text { al. }{ }^{2}\end{array}$ & 2016 & $\mathrm{C}$ & 100 & $\begin{array}{l}\text { Non-elastic } \\
\text { cotton thread } \\
\text { / Digital } \\
\text { Vernier caliper }\end{array}$ & $6.40 \pm 1.3$ & $6.43 \pm 1.15$ & $\begin{array}{l}6.72 \quad \pm \\
1.12\end{array}$ \\
\hline $\begin{array}{ll}\begin{array}{l}\text { Kaur } \\
\text { al. }\end{array} & \text { et } \\
\end{array}$ & 2013 & $\mathrm{C}$ & 100 & Silk thread & 6.17 & 6.31 & 5.18 \\
\hline $\begin{array}{l}\text { Almeda et } \\
\text { al. }^{6}\end{array}$ & 2004 & $\mathrm{C}$ & 22 & $\begin{array}{l}\text { Analogical } \\
\text { Pachymeter/ } \\
\text { Vernier caliper }\end{array}$ & $\begin{array}{l}5.92 \quad \pm \\
1.37\end{array}$ & $5.31 \pm 1.06$ & $\begin{array}{l}5.91 \\
1.13\end{array}$ \\
\hline $\begin{array}{l}\text { Dhananjay } \\
\text { a et al. }{ }^{7}\end{array}$ & 2013 & $\mathrm{C}$ & 40 & $\begin{array}{ll}\text { Sagittal and } \\
\text { coronal } \\
\text { T1weighted } \\
\text { and } \\
\text { weighted } \\
\text { MRI images }\end{array}$ & $6.3 \pm 1.1$ & $5.2 \pm 1.3$ & $6.9 \pm 1.1$ \\
\hline $\begin{array}{l}\text { Hathila et } \\
\text { al. } 8\end{array}$ & 2018 & $\mathrm{C}$ & 30 & $\begin{array}{ll}\text { Digital } & \\
\text { Vernier } & \\
\text { Calliper \& } & \\
\text { analysed } & \\
\text { with } \quad \text { MS } \\
\text { Excel } & \\
\end{array}$ & $6.21 \pm 0.6$ & $6.18 \pm 0.55$ & $\begin{array}{l}6.30 \\
0.42\end{array}$ \\
\hline $\begin{array}{l}\text { Bloecker } \\
\text { et al. }{ }^{9}\end{array}$ & 2011 & $\mathrm{H}$ & $\begin{array}{l}\text { Not } \\
\text { mentio } \\
\text { ned }\end{array}$ & $\begin{array}{l}\text { MR Imaging } \\
/ \quad 3 \mathrm{D} \\
\text { morphometri c } \\
\text { analysis }\end{array}$ & $7.7 \pm 1.3 \mathrm{~mm}$ & & \\
\hline
\end{tabular}

Average thickness: anterior third $5.40 \pm 0.5$ to $6.40 \pm 1.3 \mathrm{~mm}$ middle third $5.2 \pm 1.3$ to $6.43 \pm 1.15$ mm posterior third $5.2 \pm 1.3$ to $6.43 \pm 1.15 \mathrm{~mm}$; C - Cadaver; $\mathbf{H}$ - Healthy male 
Table 2: Thickness of lateral meniscus

\begin{tabular}{|c|c|c|c|c|c|c|c|}
\hline \multirow[b]{2}{*}{ Author } & \multirow[b]{2}{*}{ Year } & \multirow{2}{*}{$\begin{array}{l}\text { Type } \\
\text { of } \\
\text { study }\end{array}$} & \multirow{2}{*}{$\begin{array}{l}\text { No. } \\
\text { of } \\
\text { Knee } \\
\text { Joint }\end{array}$} & \multirow[b]{2}{*}{ Method } & \multicolumn{3}{|c|}{ Lateral meniscus } \\
\hline & & & & & $\begin{array}{l}\text { Anterior } \\
(\mathbf{m m})\end{array}$ & $\begin{array}{l}\text { Middle } \\
\text { (mm) }\end{array}$ & $\begin{array}{l}\text { Posterior } \\
(\mathrm{mm})\end{array}$ \\
\hline Rao et al. ${ }^{1}$ & 2014 & $\mathrm{C}$ & 100 & $\begin{array}{l}\text { Non-elastic } \\
\quad \text { cotton } \\
\text { thread / Vernier } \\
\text { caliper }\end{array}$ & $\begin{array}{l}5.90 \quad \pm \\
0.33\end{array}$ & $\begin{array}{l}5.00 \pm \\
0.56\end{array}$ & $\begin{array}{l}5.70 \quad \pm \\
0.40\end{array}$ \\
\hline $\begin{array}{l}\text { Rohila et } \\
\text { al. }^{2}\end{array}$ & 2016 & $\mathrm{C}$ & 100 & $\begin{array}{l}\text { Non-elastic } \\
\text { cotton } \\
\text { thread / Digital } \\
\text { Vernier caliper }\end{array}$ & $\begin{array}{l}4.73 \pm \\
1.12\end{array}$ & $\begin{array}{l}6.75 \pm \\
1.13\end{array}$ & $\begin{array}{l}6.18 \\
0.99\end{array}$ \\
\hline Kaur et al. ${ }^{5}$ & 2013 & $\mathrm{C}$ & 100 & Silk thread & 4.40 & 6.52 & 5.46 \\
\hline $\begin{array}{l}\text { Almeda et } \\
\text { al. }{ }^{6}\end{array}$ & 2004 & $\mathrm{C}$ & 22 & $\begin{array}{l}\text { Analogical } \\
\text { Pachymeter/ } \\
\text { Vernier caliper }\end{array}$ & $\begin{array}{l}3.71 \quad \pm \\
1.15\end{array}$ & $\begin{array}{l}6.10 \pm \\
1.104\end{array}$ & $\begin{array}{l}5.29 \\
0.78\end{array}$ \\
\hline $\begin{array}{l}\text { Dhananjaya } \\
\text { et } \\
\text { al. }^{7}\end{array}$ & 2013 & $\mathrm{C}$ & 40 & $\begin{array}{lr}\text { Sagittal and } & \\
\text { coronal T1- } \\
\text { weighted } \\
\text { nd } \\
\text { weighted MRI } \\
\text { images }\end{array}$ & $4.8 \pm 0.7$ & $\begin{array}{l}6.4 \pm \\
1.1\end{array}$ & $\begin{array}{l}7.0 \pm \\
0.60\end{array}$ \\
\hline $\begin{array}{l}\text { Hathila et } \\
\text { al. }{ }^{8}\end{array}$ & 2018 & $\mathrm{C}$ & 30 & $\begin{array}{lr}\text { Digital } & \text { Vernier } \\
\text { Caliper } & \& \\
\text { analysed } & \text { with } \mathrm{MS} \\
\text { Excel } & \\
\end{array}$ & $4.5 \pm 0.5$ & $\begin{array}{l}5.90 \pm \\
0.61\end{array}$ & $\begin{array}{l}5.63 \\
0.60\end{array}$ \\
\hline $\begin{array}{l}\text { Bloecker et } \\
\text { al. }{ }^{9}\end{array}$ & 2011 & $\mathrm{H}$ & $\begin{array}{l}\text { Not } \\
\text { menti } \\
\text { oned }\end{array}$ & $\begin{array}{l}\text { MR Imaging } \\
/ 3 \mathrm{D} \\
\text { morphometric } \\
\text { analysis }\end{array}$ & $7.2 \pm 1.0 \mathrm{~m}$ & & \\
\hline
\end{tabular}

Average thickness: anterior third $3.71 \pm 1.15$ to $5.90 \pm 0.33 \mathrm{~mm}$ middle third $5.00 \pm 0.56$ to $6.75 \pm 1.13$ mm posterior third $5.29 \pm 0.78$ to $7.0 \pm 0.60 \mathrm{~mm}$.

Table 3: Width of medial meniscus

\begin{tabular}{|c|c|c|c|c|c|c|c|c|}
\hline \multirow{3}{*}{\begin{tabular}{|l} 
Author \\
Rao et al. ${ }^{1}$
\end{tabular}} & \multirow{3}{*}{\begin{tabular}{|l} 
Year \\
2014
\end{tabular}} & \multirow{3}{*}{\begin{tabular}{|l}
$\begin{array}{l}\text { Type of } \\
\text { study }\end{array}$ \\
C \\
\end{tabular}} & \multirow{3}{*}{ 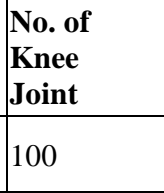 } & \multirow{3}{*}{\begin{tabular}{|l} 
Method \\
$\begin{array}{l}\text { Non-elastic cotton thread / } \\
\text { Vernier caliper }\end{array}$ \\
\end{tabular}} & \multicolumn{4}{|c|}{ Medial meniscus } \\
\hline & & & & & $\begin{array}{l}\text { Anterior } \\
(\mathbf{m m})\end{array}$ & \multirow{2}{*}{\begin{tabular}{|l|}
$\begin{array}{l}\text { Middle } \\
(\mathbf{m m})\end{array}$ \\
$10.50 \pm$ \\
1.20 \\
\end{tabular}} & \multicolumn{2}{|l|}{\begin{tabular}{|l} 
Posterior \\
$(\mathbf{m m})$
\end{tabular}} \\
\hline & & & & & $\begin{array}{ll}8.30 & \pm \\
1.06 & \end{array}$ & & $\begin{array}{l}15.80 \\
2035\end{array}$ & \\
\hline Rohila et al. $^{2}$ & 2016 & C & 100 & $\begin{array}{l}\text { Non-elastic cotton thread / Digital } \\
\text { Vernier caliper }\end{array}$ & $\begin{array}{l}7.37 \\
1.06 \\
\end{array}$ & $\begin{array}{l}10.82 \pm \\
1.69 \\
\end{array}$ & \begin{tabular}{|l|}
14.34 \\
2.37 \\
\end{tabular} & \pm \\
\hline Kaur et al. ${ }^{5}$ & 2013 & C & 100 & Silk thread & $\begin{array}{l}7.68 \\
1.36\end{array}$ & $\begin{array}{l}9.32 \\
2.24 \\
\end{array}$ & $\begin{array}{l}14.96 \\
2.66\end{array}$ & \pm \\
\hline Almeda et al. ${ }^{6}$ & 2004 & C & 22 & $\begin{array}{l}\text { Analogical Pachymeter/ } \\
\text { Vernier caliper }\end{array}$ & $\begin{array}{ll}9.02 & \pm \\
1.59 & \end{array}$ & $\begin{array}{l}12.16 \pm \\
2.58\end{array}$ & $\begin{array}{l}17.37 \\
2.22\end{array}$ & \\
\hline $\begin{array}{l}\text { Dhananjaya et } \\
\text { al. }{ }^{7}\end{array}$ & 2013 & C & 40 & $\begin{array}{l}\text { Sagittal and coronal T1-weighted } \\
\text { and T2 weighted MRI images }\end{array}$ & $\begin{array}{ll}10.02 & \pm \\
1.59\end{array}$ & $7.8 \pm 1$ & $13.9 \pm 0.8$ & \\
\hline Hathila et al. ${ }^{8}$ & 2018 & C & 30 & $\begin{array}{l}\text { Digital Vernier Caliper \& } \\
\text { analysed with MS Excel }\end{array}$ & $\begin{array}{ll}9.05 & \pm \\
0.70 & \end{array}$ & $\begin{array}{l}11.10 \pm \\
0.45\end{array}$ & $\begin{array}{l}15.39 \\
0.58\end{array}$ & \\
\hline Bloecker et al. ${ }^{9}$ & 2011 & $\mathrm{H}$ & $\begin{array}{l}\text { Not mentio } \\
\text { ned }\end{array}$ & $\begin{array}{l}\text { MR Imaging / } \\
\text { 3D morphometric analysis }\end{array}$ & $9.9 \pm 1.0 \mathrm{~m}$ & & & \\
\hline
\end{tabular}

Average width: anterior third $7.37 \pm 1.06$ to $10.02 \pm 1.5 \mathrm{~mm}$ middle third $7.8 \pm 1$ to 12.16

$\pm 2.58 \mathrm{~mm}$ posterior third $13.9 \pm 0.8$ to $17.37 \pm 2.22 \mathrm{~mm}$. 
Table 4: Width of lateral meniscus

\begin{tabular}{|c|c|c|c|c|c|c|c|}
\hline \multirow[b]{2}{*}{ Author } & \multirow[b]{2}{*}{ Year } & \multirow{2}{*}{$\begin{array}{l}\text { Type } \\
\text { of } \\
\text { study }\end{array}$} & \multirow{2}{*}{$\begin{array}{l}\text { No. of } \\
\text { Knee } \\
\text { Joint }\end{array}$} & \multirow[b]{2}{*}{ Method } & \multicolumn{3}{|c|}{ Medial meniscus } \\
\hline & & & & & $\begin{array}{l}\text { Anterior } \\
(\mathrm{mm})\end{array}$ & $\begin{array}{l}\text { Middle } \\
(\mathrm{mm})\end{array}$ & $\begin{array}{l}\text { Posterior } \\
(\mathrm{mm})\end{array}$ \\
\hline Rao et al. ${ }^{1}$ & 2014 & $\mathrm{C}$ & 100 & $\begin{array}{l}\text { Non-elastic } \\
\text { cotton thread / } \\
\text { Vernier } \\
\text { caliper }\end{array}$ & $\begin{array}{l}9.90 \quad \pm \\
1.16\end{array}$ & $\begin{array}{l}9.70 \pm \\
0.61\end{array}$ & $\begin{array}{l}9.80 \pm \\
1.16\end{array}$ \\
\hline $\begin{array}{l}\text { Rohila et } \\
\text { al. }{ }^{2}\end{array}$ & 2016 & $\mathrm{C}$ & 100 & $\begin{array}{l}\text { Non-elastic } \\
\text { cotton thread / } \\
\text { Digital } \\
\text { Vernier } \\
\text { caliper } \\
\end{array}$ & $\begin{array}{l}9.93 \quad \pm \\
1.71\end{array}$ & $\begin{array}{l}11.21 \pm \\
2.91\end{array}$ & $\begin{array}{l}11.03 \pm \\
1.40\end{array}$ \\
\hline Kaur et al. ${ }^{5}$ & 2013 & $\mathrm{C}$ & 100 & Silk thread & $\begin{array}{l}11.32 \pm \\
1.46\end{array}$ & $\begin{array}{l}11.16 \pm \\
1.64\end{array}$ & $\begin{array}{l}11.67 \pm \\
1.54\end{array}$ \\
\hline $\begin{array}{l}\text { Almeda et } \\
\text { al. }{ }^{6}\end{array}$ & 2004 & $\mathrm{C}$ & 22 & $\begin{array}{l}\text { Analogical } \\
\text { Pachymeter/ } \\
\text { Vernier } \\
\text { caliper }\end{array}$ & $\begin{array}{l}11.86 \pm \\
1.81\end{array}$ & $\begin{array}{l}11.97 \pm \\
2.56\end{array}$ & $\begin{array}{l}11.4 \pm \\
1.07\end{array}$ \\
\hline $\begin{array}{l}\text { Dhananjaya } \\
\text { et } \\
\text { al. }^{7}\end{array}$ & 2013 & $\mathrm{C}$ & 40 & $\begin{array}{l}\text { Sagittal and } \\
\text { coronal T1- } \\
\text { weighted and } \\
\text { T2 weighted } \\
\text { MRI } \\
\text { images }\end{array}$ & $\begin{array}{l}11.8 \pm \\
1.4\end{array}$ & $\begin{array}{l}8.6 \pm \\
1.2\end{array}$ & $\begin{array}{l}12.0 \pm \\
0.9\end{array}$ \\
\hline $\begin{array}{l}\text { Hathila et } \\
\text { al. }{ }^{8}\end{array}$ & 2018 & $\mathrm{C}$ & 30 & $\begin{array}{l}\text { Digital } \\
\text { Vernier } \\
\text { Caliper \& \& } \\
\text { analysed with } \\
\text { MS Excel }\end{array}$ & $\begin{array}{l}11.82 \pm \\
0.81\end{array}$ & $\begin{array}{l}12.53 \pm \\
0.72\end{array}$ & $\begin{array}{l}12.03 \pm \\
0.8\end{array}$ \\
\hline $\begin{array}{l}\text { Bloecker et } \\
\text { al. } 9\end{array}$ & 2011 & $\mathrm{H}$ & $\begin{array}{l}\text { Not } \\
\text { mentio } \\
\text { ned }\end{array}$ & $\begin{array}{l}\text { MR Imaging / } \\
\text { 3D } \\
\text { morphometric } \\
\text { analysis }\end{array}$ & $10.1 \pm 1.2$ & $\mathrm{~mm}$ & \\
\hline
\end{tabular}

Average width: anterior third $7.37 \pm 1.0$ to $11.86 \pm 1.81 \mathrm{~mm}$ middle third $8.6 \pm 1.2$ to $12.53 \pm 0.72$ mm posterior third $9.80 \pm 1.16$ to $12.03 \pm 0.8 \mathrm{~mm}$

Table 5: Length of outer circumference of menisci

\begin{tabular}{|c|c|c|c|c|c|c|}
\hline Author & Year & $\begin{array}{l}\text { Type of } \\
\text { study }\end{array}$ & $\begin{array}{l}\text { No. of } \\
\text { Knee } \\
\text { Joint }\end{array}$ & Method & $\begin{array}{l}\text { Medial } \\
\text { meniscus }\end{array}$ & $\begin{array}{l}\text { Lateral } \\
\text { meniscus }\end{array}$ \\
\hline Rao et al. ${ }^{1}$ & 2014 & $\mathrm{C}$ & 100 & $\begin{array}{l}\text { Non-elastic cotton } \\
\text { thread /Vernier } \\
\text { caliper }\end{array}$ & $\begin{array}{l}86.4 \pm \\
0.27 \mathrm{~mm}\end{array}$ & $\begin{array}{l}87.3 \pm 0.65 \\
\mathrm{~mm}\end{array}$ \\
\hline $\begin{array}{l}\text { Rohila et } \\
\text { al. }^{2}\end{array}$ & 2016 & $\mathrm{C}$ & 100 & $\begin{array}{l}\text { Non-elastic cotton } \\
\text { thread /Digital } \\
\text { Vernier caliper }\end{array}$ & $\begin{array}{l}10.50 \pm \\
0.65 \mathrm{~cm}\end{array}$ & $\begin{array}{l}10.15 \pm 0.72 \\
\mathrm{~cm}\end{array}$ \\
\hline $\begin{array}{l}\text { Kaur et } \\
\text { al. } .^{5}\end{array}$ & 2013 & $\mathrm{C}$ & 100 & Silk thread & $\begin{array}{l}91.85 \pm \\
5.6 \mathrm{~mm}\end{array}$ & $\begin{array}{l}92.80 \pm 7.52 \\
\mathrm{~mm}\end{array}$ \\
\hline $\begin{array}{l}\text { Hathila et } \\
\text { al.8 }\end{array}$ & 2018 & $\mathrm{C}$ & 30 & $\begin{array}{l}\text { Digital } \\
\text { Vernier } \\
\text { Caliper \& analysed } \\
\text { with } \quad \text { MS } \\
\text { Excel }\end{array}$ & $\begin{array}{l}10.28 \mathrm{~cm} \\
\pm 0.77 \\
\mathrm{~cm}\end{array}$ & $\begin{array}{l}9.64 \pm 0.33 \\
\mathrm{~mm}\end{array}$ \\
\hline
\end{tabular}

Average: Medial menisci ranges as $86.4 \pm 0.27 \mathrm{~mm}$ to $10.50 \pm 0.65 \mathrm{~cm}$ and Lateral menisci ranges as $87.3 \pm 0.65 \mathrm{~mm}$ to $10.15 \pm 0.72 \mathrm{~cm}$ 
Table 6: Distance between anterior and posterior horn of menisci

\begin{tabular}{|c|c|c|c|c|c|c|}
\hline Author & Year & $\begin{array}{ll}\text { Type of } \\
\text { study }\end{array}$ & $\begin{array}{ll}\text { No. of } \\
\text { Knee } \\
\text { Joint }\end{array}$ & Method & $\begin{array}{l}\text { Medial } \\
\text { meniscus }\end{array}$ & $\begin{array}{l}\text { Lateral } \\
\text { meniscus }\end{array}$ \\
\hline $\begin{array}{l}\text { Rao et } \\
\text { al. }{ }^{1}\end{array}$ & 2014 & C & 100 & $\begin{array}{l}\text { Non- } \\
\text { elastic } \\
\text { cotton } \\
\text { thread / } \\
\text { Vernier } \\
\text { caliper }\end{array}$ & $\begin{array}{l}31.8 \pm \\
0.33 \mathrm{~mm}\end{array}$ & $\begin{array}{l}12.6 \pm 0.98 \\
\mathrm{~mm}\end{array}$ \\
\hline $\begin{array}{l}\text { Rohila et } \\
\text { al. }{ }^{2}\end{array}$ & 2016 & C & 100 & $\begin{array}{l}\text { Non- } \\
\text { elastic } \\
\text { cotton } \\
\text { thread / } \\
\text { Digital } \\
\text { Vernier } \\
\text { caliper }\end{array}$ & $\begin{array}{l}3.25 \pm \\
0.37 \mathrm{~cm}\end{array}$ & $\begin{array}{l}1.71 \pm 0.40 \\
\mathrm{~cm}\end{array}$ \\
\hline $\begin{array}{l}\text { Kaur et } \\
\text { al. } 5\end{array}$ & 2013 & $\mathrm{C}$ & 100 & Silk thread & $\begin{array}{l}25.88 \pm \\
3.33 \\
\mathrm{~mm}\end{array}$ & $\begin{array}{l}12.55 \pm 1.98 \\
\mathrm{~mm}\end{array}$ \\
\hline
\end{tabular}

Average: Medial menisci ranges as $25.88 \pm 3.33 \mathrm{~mm}$ to $3.25 \pm 0.37 \mathrm{~cm}$ Lateral menisci ranges as $12.6 \pm 0.8 \mathrm{~mm}$ to $12.55 \pm 1.98 \mathrm{~mm}$. 